\title{
LABA PER SAHAM DAN UKURAN : KARAKTERISTIK PEMBAYAR DIVIDEN ?
}

\author{
Oleh: \\ Winston Pontoh \\ Fakultas Ekonomi dan Bisnis \\ Universitas Sam Ratulangi Manado \\ Email: winston_pontoh@yahoo.com
}

\begin{abstract}
ABSTRAK
Dividen merupakan salah satu komponen pengembalian yang sangat diharapkan oleh setiap investor selain keuntungan dari kelebihan atas harga saham. Selain itu, ukuran perusahaan dapat merupakan variabel yang berkontribusi dalam menentukan besarnya pembayaran dividen. Penelitian ini dilakukan pada 378 perusahaan yang terdaftar pada Bursa Efek Indonesia dalam periode 2009 sampai dengan tahun 2011 dengan menggunakan metode analisis regresi logistik dan metode uji beda rata-rata. Hasil penelitian ini menunjukkan bahwa laba per saham (EPS) berpengaruh signifikan terhadap jumlah pembayaran dividen, sedangkan ukuran perusahaan tidak berpengaruh signifikan. Kontroversi atas ukuran perusahaan, diuraikan lebih lanjut berdasarkan jenis perusahaan pembayar dividen, dan ditemukan bahwa ukuran perusahaan merupakan salah satu karakteristik perusahaan pembayar dividen. Dengan menelaah lebih jauh variabel laba per saham, maka karakteristik yang muncul adalah bahwa perusahaan yang membayar dividen secara penuh memiliki nilai laba bersih yang tinggi dan memiliki jumlah saham beredar yang lebih sedikit. Dalam konfirmasi akhir, dapat diketahui bahwa, perusahaan-perusahaan yang membayar dividen bukan merupakan jenis perusahaan sapi perah.
\end{abstract}

Kata Kunci : laba per saham, ukuran perusahaan, jumlah saham, laba bersih, dividen

\section{ABSTRACT}

Dividend is the main component of return that is very expected by investors, beside of capital gain. Also, the size of company could become as contribute variable to determine the amount of dividend payment. This study had samples for 378 companies listed in Indonesia Stock Exchange for period of 2009 till 2011, conducting logistic regression analysis and paired samples $t$ test. The result of study shows that, earnings per share had significant relationship with the amount of dividend payent, while size of company had not. The controversy of size's result is analyzed further based on companies who had paid the dividend, and found that, size of company is one of characteristics of companies who paid dividend. More analysis conducted to earnings per share, it is found that, companies who paid dividend have characteristics such as higher net income and less outstanding shares. In the last confirmation, this study found that, companies who always paid dividend were not a type of cash cow companies.

Keywords : earnings per share, company size, shares amout, net income, dividend 


\section{PENDAHULUAN}

Pengembalian atas investasi saham yang disertai dengan keuntungan adalah merupakan tujuan dari investor (disebut sebagai pemegang saham) untuk meningkatkan kesejahteraannya (wealth). Dividen merupakan salah satu komponen pengembalian (return) yang sangat diharapkan oleh setiap investor selain keuntungan dari kelebihan atas harga saham (capital gain), walaupun beberapa jenis investor tidak memiliki ketertarikan atas jumlah dividen yang akan dibayarkan (Barclay, et. al., 2009). Akan tetapi, tidak dapat dipungkiri bahwa, harapan investor atas dividen akan selalu mengalami peningkatan dari tahun ke tahun. Laba per saham diyakini sebagai faktor utama dalam menentukan jumlah pembayaran dividen (Ross et. al., 2008), sehingga laba per saham juga diyakini sebagai fungsi dari perubahan-perubahan dari dividen yang akan dibayarkan karena dapat dikaitkan dengan kemampuan menciptakan laba di masa depan dari perusahaan itu sendiri.

Hubungan laba per saham (earnings per share) dan ukuran perusahaan dengan jumlah pembayaran dividen telah banyak dibuktikan dalam penelitian-penelitian sebelumnya, dan bukan sesuatu hal yang baru lagi di dalam dunia praktisi. Penelitian ini bertujuan memberikan kontribusi tambahan lainnya tentang hubungan antara laba per saham dan ukuran perusahaan dengan jumlah pembayaran dividen secara lebih mendalam dikaitkan dengan beberapa karakteristik perusahaan, agar investor dapat memiliki informasi tambahan lainnya tentang karakteristik-karakteristik perusahaan pembayar dividen yang dapat mengembalikan investasi atas sahamnya.

Beberapa karakteristik perusahaan yang diduga memiliki hubungan dengan pembayaran dividen sebuah perusahaan, akan diuraikan dengan menganalisis, tren pembayaran dividen dari setiap perusahaan, hubungan antara ukuran perusahaan dengan tren pembayaran dividen, hubungan komponen-komponen dalam penentuan laba per saham (earnings per share - EPS) dengan tren pembayaran dividen.

\section{TINJAUAN PUSTAKA}

Secara tidak langsung, adanya dividen yang dibayarkan oleh perusahaan kepada pemegang saham mencerminkan prospek masa depan dari perusahaan itu sendiri (Aharony \& Swary, 1980 ; Black, 1996). Selain itu, Shiller (1981), Battacharya \& Hakansson (1982), Campbell \& Shiller (1988), dan Adelegan (2003), menyatakan bahwa, laba per saham (earnings per share) merupakan salah satu fungsi dari perubahan-perubahan dividen yang akan dibayarkan. Bernheim (1991), berpendapat bahwa, perusahaan yang melakukan pembayaran tunai (dividen) kepada pemegang sahamnya, pada umumnya memberikan isyarat (signal) akan adanya kemampuan menciptakan laba dari perusahaan tersebut, setelah mempertimbangkan faktor pembayaran pajak dari perusahaan.

Ross et. al. (2008), berpendapat bahwa, secara ideal, jumlah dividen yang dibayarkan adalah sama dengan laba per saham (earnings per share - EPS) yang diumumkan, akan tetapi Ross et. al. (2008) menyatakan bahwa, jenis perusahaan yang membayarkan dividen sama dengan jumlah laba per sahamnya adalah perusahaan yang dapat dikategorikan sebagai jenis perusahaan sapi perah (cash cow). Pendapat yang sama diajukan oleh Berens \& Cuny (1995) dan Brennan \& Thakor (1990), yang menyatakan bahwa, seluruh laba setelah pajak dari sebuah perusahaan dapat dibayarkan kepada pemegang saham, dalam bentuk dividen atau dapat digunakan untuk melakukan pembelian kembali atas saham perusahaan tersebut (treasury stocks).

Ryan et. al. (2000), dalam penelitiannya, menemukan bahwa, adanya perubahan dalam pembayaran dividen kepada pemegang saham, dapat dijelaskan dengan adanya teori arus kas bebas (free cash flow theory) dan juga dapat dikaitkan dengan ukuran (size) perusahaan. Hasil penelitian ini didukung oleh Adelegan (2003), yang menemukan bahwa, ukuran (size) sebuah perusahaan dapat menjelaskan adanya perubahan negatif untuk pembayaran dividen, 
khususnya perusahaan besar. Dampak dari ukuran (size) perusahaan terhadap laba menurut Cabral (1995) adalah apabila terdapat biaya terbenam (sunk costs), maka perusahaan dengan ukuran yang lebih besar memiliki serangkaian kapasitas yang identik dengan waktu jangka panjang, sedangkan perusahaan dengan ukuran lebih kecil, pada umumnya hanya melakukan investasi untuk memenuhi sebagian dari kapasitas jangka panjang yang optimal. Apabila harga jual produk berada pada posisi konstan, sedangkan fungsi biaya mengalami peningkatan, maka pengurangan laba dari kapasitas suboptimal tidak akan melebihi dari proporsional penurunan kapasitas optimalnya. Implikasinya adalah bahwa tingkat laba akan mengalami peningkatan apabila kapasitas produksi diatur pada tingkat yang optimum.

Terkait dengan pengaruh ukuran perusahaan terhadap pembayaran dividen, Redding (1997), menemukan bahwa, ukuran perusahaan yang lebih besar cenderung membayar dividen dibandingkan dengan perusahaan yang lebih kecil. Hasil penelitian ini didukung oleh Fama \& French (2002), menggunakan ukuran perusahaan sebagai proksi kerentanan laba (earnings volatility) dan menemukan bahwa ukuran perusahaan memiliki pengaruh terhadap keputusan pembayaran dividen. Hasil yang sama juga dikemukakan oleh Rafique (2012), yang menemukan bahwa, ukuran berpengaruh signifikan terhadap kebijakan dividen. Moradi, et. al. (2010), menemukan bahwa, ukuran tidak berpengaruh signifikan terhadap kebijakan dividen. Erasmus (2013), dalam penelitiannya memberikan catatan bahwa, terjadinya bias dari hasil analisis kemungkinan besar akan terjadi, apabila sampel yang diteliti terkait dengan pembayaran dividen adalah perusahaan-perusahaan yang memiliki ukuran yang besar.

\section{METODE PENELITIAN}

\subsection{Jenis dan Sumber Data}

Jenis data dalam penelitian ini adalah data kuantitatif yang berupa data rasio keuangan yang berasal dari laporan keuangan audit dan terpublikasi untuk periode tahun 2009 sampai dengan tahun 2011. Sedangkan sumber data dalam penelitian ini adalah berasal dari Bursa Efek Indonesia (BEI).

\subsection{Populasi dan Sampel}

Populasi dalam penelitian ini adalah seluruh perusahaan yang terdaftar dalam Bursa Efek Indonesia atau sebanyak 446 perusahaan, dimana, berdasarkan metode purposive sampling, sejumlah 378 perusahaan diambil sebagai sampel penelitian $(84.75 \%$ dari populasi $)$ karena menerbitkan laporan keuangan dan diaudit secara berturut-turut selama 3 tahun, serta kelayakan lainnya untuk kebutuhan penelitian, sehingga total data observasi dalam penelitian adalah 1.134 .

\begin{tabular}{lrrrrr}
\hline \multicolumn{1}{c}{ SEKTOR } & JUMLAH & Div0 & Div1 & Div2 & Div3 \\
\hline Agriculture & 15 & 6 & 1 & 2 & 6 \\
Mining & 25 & 10 & 2 & 7 & 6 \\
Basic Industry \& Chemicals & 56 & 28 & 3 & 11 & 14 \\
Miscellaneous Industry & 39 & 22 & 3 & 4 & 10 \\
Consumer Goods Industry & 29 & 10 & 4 & 3 & 12 \\
Property, Real Estate \& Building Construction & 41 & 19 & 5 & 6 & 11 \\
Infrastructure, Utilities \& Transportation & 25 & 14 & 4 & 2 & 5 \\
Finance & 67 & 27 & 9 & 10 & 21 \\
Trade, Services \& Investment & 81 & 38 & 7 & 10 & 26 \\
\hline JUMLAH & $\mathbf{3 7 8}$ & $\mathbf{1 7 4}$ & $\mathbf{3 8}$ & $\mathbf{5 5}$ & $\mathbf{1 1 1}$ \\
\hline
\end{tabular}

\subsection{Metode Analisis}

Dalam penelitian ini, metode analisis yang akan digunakan sebagai alat pengujian hipotesis adalah metode analisis regresi logistik dengan model analisis varians (analysis of variance - ANOVA), model analisis kovarians (analysis of covariance - ANCOVA), dan metode uji beda rata-rata (paired samples t test). 


\subsection{Definisi Operasional dan Pengukuran Variabel}

1. Dividen adalah jumlah pembayaran dividen, dimana variabel akan dikategorikan dengan variabel dummy berdasarkan jenis : perusahaan yang membayar dividen 0 tahun (Div0), perusahaan yang membayar dividen untuk 1 tahun (Div1), perusahaan yang membayar dividen untuk 2 tahun (Div2), dan perusahaan yang membayar dividen untuk 3 tahun (Div3). Dalam analisis lanjut, Div3 akan menjadi variabel referensi/pembanding.

2. Ukuran (size) adalah ukuran perusahaan, dimana, berdasarkan Fama \& French (2002) dan Dalbor et. al. (2004), variabel ini diukur dengan menggunakan logaritma natural atas aset secara keseluruhan (ln total asset).

3. Laba per saham (earnings per share - EPS) adalah laba untuk setiap lembar saham, yang diukur dengan membagi jumlah laba bersih (net income) dengan jumlah saham.

\subsection{Hipotesis}

$\mathrm{Ha}_{1.1}$ : Laba per saham berpengaruh terhadap jumlah dividen.

$\mathrm{Ha}_{1.2}$ : Ukuran perusahaan berpengaruh terhadap jumlah dividen.

$\mathrm{Ha}_{1.3}$ : Dividen dari Div3 adalah berbeda signifikan dengan perusahaan lainnya.

Dividen $=\alpha+\beta$ EPS $+\beta$ Size $+\beta$ Div2 $+\beta$ Div1 $+\beta$ Div0 $+\varepsilon$

$\mathrm{Ha}_{2.1}$ : Laba per saham dari Div3 adalah berbeda signifikan dengan Div2.

$\mathrm{Ha}_{2.2}$ : Laba per saham dari Div3 adalah berbeda signifikan dengan Div1.

$\mathrm{Ha}_{2.3}$ : Laba per saham dari Div3 adalah berbeda signifikan dengan Div0.

EPS $=\alpha+\beta$ Div2 $+\beta$ Div1 $+\beta$ Div0 $+\varepsilon$

$\mathrm{Ha}_{3.1}$ : $\quad$ Ukuran dari Div3 adalah berbeda signifikan dengan Div2.

$\mathrm{Ha}_{3.2}$ : $\quad$ Ukuran dari Div3 adalah berbeda signifikan dengan Div1.

$\mathrm{Ha}_{3.3}$ : $\quad$ Ukuran dari Div3 adalah berbeda signifikan dengan Div0.

Size $=\alpha+\beta$ Div2 $+\beta$ Div1 $+\beta$ Div0 $+\varepsilon$

$\mathrm{Ha}_{4.1}$ : Laba bersih dari Div3 adalah berbeda signifikan dengan Div2.

$\mathrm{Ha}_{4.2}$ : Laba bersih dari Div3 adalah berbeda signifikan dengan Div1.

$\mathrm{Ha}_{4.3}$ : Laba bersih dari Div3 adalah berbeda signifikan dengan Div0.

Laba Bersih $=\alpha+\beta$ Div2 $+\beta$ Div1 $+\beta$ Div0 $+\varepsilon$

$\mathrm{Ha}_{5.1}$ : Jumlah saham dari Div3 adalah berbeda signifikan dengan Div2.

$\mathrm{Ha}_{5.2}$ : Jumlah saham dari Div3 adalah berbeda signifikan dengan Div1.

$\mathrm{Ha}_{5.3}$ : Jumlah saham dari Div3 adalah berbeda signifikan dengan Div0.

Jumlah Saham $=\alpha+\beta$ Div2 $+\beta$ Div1 $+\beta$ Div0 $+\varepsilon$

$\mathrm{Ha}_{6}$ : Laba per saham berbeda signifikan dengan jumlah dividen.

EPS $_{\text {Div3 }} \neq$ Dividen $_{\text {Div3 }}$

\section{HASIL DAN PEMBAHASAN}

\subsection{Hasil}

Hasil pengujian hipotesis 1 (Tabel 1) dengan model ANCOVA, menunjukkan bahwa, secara parsial, laba per saham (EPS) memiliki pengaruh signifikan ( $\mathrm{Ha}_{1.1}$ diterima) terhadap jumlah dividen yang dibayarkan, sedangkan ukuran perusahaan (size) tidak berpengaruh signifikan ( $\mathrm{Ha}_{1.2}$ ditolak). Selain itu, hasil analisis juga menunjukkan bahwa, jumlah dividen dari perusahaan-perusahaan yang membayar dividen secara penuh selama 3 (tiga) tahun penuh memiliki nilai yang lebih tinggi (sebesar Rp. 268.605) daripada perusahaan- 
perusahaan yang jarang atau tidak membayar dividen dalam kurun waktu 3 (tiga) tahun, dimana perbedaan nilai dividen tersebut adalah signifikan $\left(\mathrm{Ha}_{1.3}\right.$ diterima). Berdasarkan nilai $\mathrm{R}$, diketahui bahwa, hubungan variabel dependen dengan variabel independen adalah bersifat sedang, dan variabel independen memiliki kontribusi untuk menjelaskan model variabel dependen sebesar $26.3 \%$ atau $26 \%$.

Hasil pengujian hipotesis 2 (Tabel 2) dengan model ANOVA, menunjukkan bahwa, nilai laba per saham (EPS) dari Div3 memiliki nilai yang lebih tinggi (sebesar Rp. 652.043) dibandingkan dengan perusahaan lainnya, dimana laba per saham dari Div3 adalah berbeda signifikan dengan Div1 ( $\mathrm{Ha}_{2.2}$ diterima) dan juga Div0 ( $\mathrm{Ha}_{2.3}$ diterima), sedangkan dengan Div2 tidak mengalami perbedaan yang signifikan ( $\mathrm{Ha}_{2.1}$ ditolak).

Hasil pengujian hipotesis 3 (Tabel 3) dengan model ANOVA, menunjukkan bahwa, ukuran perusahaan (size) dari Div3 memiliki nilai yang lebih besar (sebesar 14.968) dibandingkan dengan perusahaan lainnya, dengan perbedaan yang muncul adalah signifikan $\left(\mathrm{Ha}_{3.1}, \mathrm{Ha}_{3.2}\right.$, dan $\mathrm{Ha}_{3.3}$ diterima).

Hasil pengujian hipotesis 4 (Tabel 4) dengan model ANOVA, menunjukkan bahwa, laba bersih (net income) dari Div3 memiliki nilai yang lebih tinggi (sebesar Rp. 1,257,856) dibandingkan dengan perusahaan lainnya, dengan perbedaan yang muncul adalah signifikan ( $\mathrm{Ha}_{4.1}, \mathrm{Ha}_{4.2}$, dan $\mathrm{Ha}_{4.3}$ diterima).

Hasil pengujian hipotesis 5 (Tabel 5) dengan model ANOVA, menunjukkan bahwa, saham beredar dari Div3 memiliki jumlah yang lebih sedikit (sebesar 3,995.610 lembar), akan tetapi tidak memiliki perbedaan yang signifikan dengan jumlah saham beredar perusahaan lainnya ( $\mathrm{Ha}_{5.1}, \mathrm{Ha}_{5.2}$, dan $\mathrm{Ha}_{5.3}$ ditolak).

Hasil pengujian hipotesis 6 (Tabel 6) dengan model ANOVA, menunjukkan bahwa, perbedaan antara jumlah dividen yang dibayarkan dengan jumlah laba per saham dari perusahaan Div3 adalah berbeda signifikan, sehingga dalam hal ini $\mathrm{Ha}_{6}$ diterima.

\subsection{Pembahasan}

Hasil penelitian ini tentang laba per saham (EPS) sesuai dengan hasil penelitian dan pendapat dari Aharony \& Swary (1980), Black (1996), Shiller (1981), Battacharya \& Hakansson (1982), Campbell \& Shiller (1988), Adelegan (2003), dan Bernheim (1991). Sedangkan untuk ukuran perusahaan, hasil penelitian ini mendukung penelitian Moradi, et. al. (2010), tapi memiliki kemiripan fungsi seperti pada hasil penelitian Adelegan (2003). Hasil analisis lanjutan dilakukan untuk mengkonfirmasi, apakah laba per saham (EPS) dan ukuran (size) perusahaan dapat menjadi karakteristik yang merupakan gambaran awal terjadinya hubungan dengan kebijakan dividen.

Hasil pengujian dengan model ANOVA (Tabel 2) menunjukkan dengan jelas bahwa nilai rata-rata laba per saham (EPS) dari perusahaan yang membayar dividen selama 3 (tiga) tahun lebih tinggi dari perusahaan pembayar dividen lainnya, sehingga dengan melihat hasil ini, secara jelas mendukung hasil pengujian hipotesis 1 (Tabel 1), dan dapat disimpulkan bahwa laba per saham (EPS) adalah salah satu karakteristik yang dapat menjadi variabel pengontrol jumlah pembayaran dividen.

Apabila unsur pembentuk laba per saham ditelaah lebih jauh, maka diperoleh 2 (dua) komponen yaitu laba bersih dan jumlah saham yang beredar. Dengan menggunakan analisis ANOVA (Tabel 4 dan Tabel 5), maka hasil yang diperoleh adalah laba bersih dari perusahaan-perusahaan yang membayar dividen selama 3 (tiga) tahun lebih tinggi dengan perusahaan-perusahaan pembayar dividen lainnya, sehingga berdasarkan hasil analisis ini, dapat disimpulkan bahwa karakteristik lainnya dari perusahaan-perusahaan yang membayar dividen selama 3 (tiga) tahun berturut-turut adalah memiliki laba bersih yang cukup tinggi. Lebih lanjut, hasil analisis atas jumlah saham yang beredar, ditemukan bahwa jumlah saham yang beredar dari perusahaan-perusahaan yang membayar dividen selama 3 (tiga) tahun berturut-turut adalah lebih sedikit dibandingkan dengan perusahaan-perusahaan lainnya. 
Hasil ini dibuktikan dengan jumlah saham yang beredar dari perusahaan-perusahaan yang tidak membayar dividen (Div0) adalah sebanyak 3,891,878 lembar saham. Berdasarkan bukti analisis ini, maka dapat disimpulkan bahwa jumlah saham beredar yang lebih sedikit merupakan salah satu karakteristik lainnya bagi perusahaan-perusahaan yang membayar dividen selama 3 (tiga) tahun berturut-turut. Penelitian ini tidak mengkonfirmasi lebih lanjut, apakah tingginya jumlah saham beredar dari perusahaan-perusahaan yang tidak membayar dividen (Div0) disebabkan karena perusahaan-perusahaan tersebut menggunakan laba bersihnya untuk membeli kembali sahamnya (treasury stocks), seperti yang dijelaskan oleh Berens \& Cuny (1995) dan Brennan \& Thakor (1990).

Sedangkan untuk ukuran (size) perusahaan, hasil analisis menunjukkan bahwa, perusahaan-perusahaan yang membayar dividen selama 3 (tiga) tahun memiliki ukuran (size) yang lebih besar dibandingkan dengan perusahaan-perusahaan lainnya, sehingga dapat disimpulkan bahwa salah satu karakteristik dari perusahaan-perusahaan yang membayar dividen selama 3 (tiga) tahun adalah memiliki ukuran (size) perusahaan yang besar. Hasil analisis ini bertentangan dengan hasil pengujian hipotesis 1 yang menunjukkan hasil tidak signifikan dan memiliki fungsi negatif. Dalam pengujian hipotesis 1, semua data perusahaan yang berukuran besar atau kecil digabungkan dan dianalisis bersama, sehingga kemungkinan yang paling mungkin adalah hasil analisis dalam pengujian hipotesis 1 menunjukkan hasil secara umum. Memperhatikan penjelasan Cabral (1995), maka masalah kapasitas optimum produksi dalam mencapai tingkat laba optimum perlu dipertimbangkan antara perusahaan yang memiliki ukuran yang lebih besar dengan perusahaan yang memiliki ukuran yang lebih kecil. Penjelasan ini dipertegas oleh Fama \& French (2002) apabila dikaitkan dengan faktor kemampuan menciptakan laba, dimana perusahaan yang memiliki ukuran yang lebih besar akan memiliki kerentanan laba yang rendah. Berdasarkan pendapat-pendapat ini maka, ukuran perusahaan dibedakan berdasarkan intensitas pembayaran dividen, sehingga pengujian atas hipotesis 3 mendukung hasil penelitian dari Redding (1997), Ryan et. al. (2000), Fama \& French (2002), dan Rafique (2012).

Konfirmasi tambahan lainnya adalah untuk menguji apakah pendapat dari Ross et. al. (2008), dimana, jenis perusahaan yang membayarkan dividen sama dengan jumlah laba per sahamnya adalah perusahaan yang dapat dikategorikan sebagai jenis perusahaan sapi perah (cash cow). Dengan menggunakan uji beda rata-rata berpasangan (Tabel 6), dapat disimpulkan bahwa perusahaan-perusahaan yang membayar dividennya secara penuh selama 3 (tiga) tahun, bukan merupakan perusahaan yang berstatus sapi perah.

\section{KESIMPULAN}

Hasil penelitian pada sampel dan periode 2009 sampai dengan 2011 menunjukkan bahwa, secara parsial, laba per saham (EPS) memiliki pengaruh yang signifikan terhadap jumlah pembayaran dividen, sedangkan ukuran perusahaan tidak memiliki pengaruh yang signifikan. Dalam analisis lanjutan, beberapa karakteristik dari perusahaan-perusahaan yang membayar dividen secara penuh, dapat mengacu pada kedua variabel ini, dimana, karakteristikkarakteristik tersebut adalah memiliki laba per saham (EPS) yang lebih tinggi dan ukuran perusahaan yang lebih besar. Dengan menelaah lebih jauh variabel laba per saham, maka karakteristik yang muncul adalah bahwa perusahaan yang membayar dividen secara penuh memiliki nilai laba bersih yang tinggi dan memiliki jumlah saham beredar yang lebih sedikit. Dalam konfirmasi akhir, dapat diketahui bahwa, perusahaan-perusahaan yang membayar dividen secara penuh selama 3 (tiga) tahun bukan merupakan jenis perusahaan sapi perah.

\section{REFERENSI}

Adelegan, Olatundun J. (2003). An Empirical Analysis of the Relationship between Cash

Flow and Dividend Changes in Nigeria. R\&D Management 15. Blackwell Publishing Ltd. 
Aharony, Joseph \& Swary, Itzhak. (1980). Quarterly Dividend and Earnings Announcements and Stockholders' Returns: An Empirical Analysis. The Journal of Finance, Vol. 35, No. 1, pp. 1-12. Blackwell Publishing for the American Finance Association.

Barclay, Michael J. et. al. (2009). Dividends and Corporate Shareholders. The Review of Financial Studies Vol. 22 No. 6. Oxford University Press.

Battacharya, Sudipto \& Hakansson, Nils. (1982). To Pay or Not to Pay Dividend. The Journal of Finance, Vol. XXXVII No. 2.

Berens, James L. \& Cuny, Charles J. (1995). The Capital Structure Puzzle Revisited. The Review of Financial Studies, Vol. 8 No. 4, pp. 1185-1208.

Bernheim, Douglas B. (1991). Tax Policy and the Dividend Puzzle. RAND Journal of Economics, Vol. 22 No. 4.

Black, Fischer. (1996). The Dividend Puzzle. The Journal of Portfolio Management, Special Issue. 8-12.

Brennan, Michael J. \& Thakor, Anjan V. (1990). Shareholder Preferences and Dividend Policy. The Journal of Finance, Vol. 45 No. 4, pp. 903-1018.

Cabral, Luis. (1995). Sunk Costs, Firm Size and Firm Growth. The Journal of Industrial Economics, Vol. 43, No. 2, pp. 161-172. Blackwell Publishing.

Campbell, John Y \& Shiller, Robert J. (1988). Stock Prices, Earnings, and Expected Dividends. The Journal of Finance, Vol. 43 No. 3.

Dalbor, Michael, et. al. (2004). An Initial Investigation of Firm Size and Debt Use by Small Restaurants Firms. The Journal of Hospitality Financial Management, Vol. 12 No. 1.

Erasmus, Pierre. (2013). The Influence of Dividend Yield and Dividend Stability on Share Returns : Implications for Dividend Policy Formulation. Journal of Economic and Financial Sciences, April, pp. 13-32.

Fama, Eugene F. \& French, Kenneth R. (2002). Testing Trade-Off and Pecking Order Predictions about Dividends and Debt. The Review of Financial Studies, Vol. 15, No. 1, pp. 1-33.

Moradi, Mehdi, et. al. (2010). Factors Affecting Dividend Policy : Empirical Evidence of Iran. Poslovna Izvrsnost Zagreb, God. IV (2010) BR. 1.

Rafique, Mahira. (2012). Factors Affecting Dividend Payout: Evidence From Listed NonFinancial Firms of Karachi Stock Exchange. Business Management Dynamics Vol.1, No.11, pp.76-92.

Redding, Lee S. (1997). Firm Size and Dividend Payouts. Journal of Financial Intermediation $6,224-248$

Ross, Stephen A. et. al. (2008). Corporate Finance, $8^{\text {th }}$ Edition. Mc Graw-Hill/Irwin.

Ryan, Patricia A. et. al. (2000). An Empirical Analysis of Reactions to Dividend Policy Changes for NASDAQ Firms. Journal of Financial and Strategic Decisions, Volume 13 Number 1, Spring.

Shiller, Robert. (1981). Do Stock Price Move too much to be Justified by Subsequent Changes in Dividends?. The American Economic Review, Vol. 71 No. 3. 


\section{LAMPIRAN}

Tabel 1

Hasil Uji Hipotesis 1 : Regresi Logistik - Model ANCOVA Variabel Dependen : Dividen

Variabel Independen : $\quad$ EPS, Size, Div2, Div1, Div0

Div3 (referensi/pembanding)

\begin{tabular}{|c|c|c|}
\hline $\mathrm{R}$ & 0.513 & \\
\hline R Square & 0.263 & \\
\hline Adj. R Square & 0.260 & \\
\hline F-value & $80.459 *$ & \\
\hline \multirow[b]{2}{*}{ Konstanta } & Koefisien & t-value \\
\hline & 268.605 & \\
\hline EPS & 0.261 & $18.971 *$ \\
\hline Size & -8.798 & -0.777 \\
\hline Div2 & -148.720 & $-2.201 *$ \\
\hline Div1 & -161.465 & $-2.082 *$ \\
\hline Div0 & -154.394 & $-2.873^{*}$ \\
\hline
\end{tabular}

*Signifikan pada tingkat $5 \%$

Tabel 2

Hasil Uji Hipotesis 2 : Regresi Logistik - Model ANOVA Variabel Dependen : $\quad$ EPS

Variabel Independen : $\quad$ Div2, Div1, Div0

\begin{tabular}{|c|c|c|}
\hline & \multicolumn{2}{|c|}{ Div3 (referensi/pembanding) } \\
\hline & Koefisien & t-value \\
\hline Konstanta & 652.043 & \\
\hline Div2 & -66.946 & -0.460 \\
\hline Div1 & -540.990 & $-3.261 *$ \\
\hline Div0 & -640.104 & $-5.970 *$ \\
\hline
\end{tabular}

*Signifikan pada tingkat $5 \%$

Tabel 3

Hasil Uji Hipotesis 3 : Regresi Logistik - Model ANOVA Variabel Dependen : Size

Variabel Independen : $\quad$ Div2, Div1, Div0

Div3 (referensi/pembanding)

\begin{tabular}{lrr}
\hline & Koefisien & \multicolumn{1}{c}{ t-value } \\
\cline { 2 - 3 } Konstanta & 14.968 & \\
Div2 & -0.444 & $-2.508^{*}$ \\
Div1 & -0.690 & $-3.419^{*}$ \\
Div0 & -1.631 & $-12.507^{*}$ \\
\hline
\end{tabular}

*Signifikan pada tingkat $5 \%$

Tabel 4

Hasil Uji Hipotesis 4 : Regresi Logistik - Model ANOVA

Variabel Dependen : Laba Bersih

Variabel Independen : $\quad$ Div2, Div1, Div0

Div3 (referensi/pembanding)

\begin{tabular}{lrr}
\hline & \multicolumn{1}{c}{ Koefisien } & \multicolumn{1}{c}{ t-value } \\
\cline { 2 - 3 } Konstanta & $1,257,856$ & \\
Div2 & $-879,894$ & $-5.938^{*}$ \\
Div1 & $-1,068,738$ & $-6.328^{*}$ \\
Div0 & $-1,236,073$ & $-11.323^{*}$ \\
\hline
\end{tabular}

*Signifikan pada tingkat $5 \%$ 
Tabel 5

Hasil Uji Hipotesis 5 : Regresi Logistik - Model ANOVA

Variabel Dependen :

Jumlah Saham

Variabel Independen :

Div2, Div1, Div0

Div3 (referensi/pembanding)

\begin{tabular}{lrr}
\hline & \multicolumn{1}{c}{ Koefisien } & t-value \\
\cline { 2 - 3 } Konstanta & 3995.610 & \\
Div2 & 647.124 & 0.000 \\
Div1 & 85.575 & 0.000 \\
Div0 & 3887883 & 1.596 \\
\hline
\end{tabular}

*Signifikan pada tingkat $5 \%$

Tabel 6

Hasil Uji Hipotesis 6 : Uji Beda Rata-Rata

\begin{tabular}{lcrrrr}
\hline Variabel & Mean & N & Mean Difference & t-value & Sig. (2-tailed) \\
\hline Dividen & 307.2919 & 333 & -344.751 & -3.455 & 0.001 \\
EPS & 652.0430 & 333 & & & \\
\hline
\end{tabular}

